\title{
Perceptions of Electronic Banking Services by Clients in the Limpopo Province of South Africa
}

\author{
Simon Chidindi \\ Department of Business Management, University of Limpopo, Turfloop Campus, South Africa \\ E-mail: simon.chindindi@ul.ac.za \\ Prof J. T. van Niekerk \\ Department of Business Management, University of Limpopo, Turfloop Campus, South Africa \\ E-mail: trevor.vanniekerk@ul.ac.za \\ Tafadzwa Matiza \\ Department of Business Management, University of Limpopo, Turfloop Campus, South Africa \\ E-mail:matizata@hotmail.com
}

Doi:10.5901/mjss.2014.v5n10p253

\section{Abstract}

The study sought to investigate the perceptions of electronic-banking services by clients in the Limpopo Province of South Africa. In this study, bank managers and clients were used as the research subjects. Questionnaires were used as research instruments. The study showed that while electronic-banking has been launched by $90 \%$ of South African banks, it showed that customer satisfaction and its relative importance may significantly differ from one e-banking service provider to the other in the same context. Similarly, it has particularly provided insight into the effect of e-banking services on overall user satisfaction. It provides evidence that the provision of superior customer service and the giving of preferential rates for online services are two most important factors that could influence user satisfaction with e-banking services in South Africa. The study recommends that more banks need to ensure that their e-banking services meet and exceed customer expectations to avoid them switching to other banks seeking utmost satisfaction. This could be done through improving services provided. Finally, it is also recommended that future research could use a different methodology and focus on extending the study across many similar banks in different countries and in different service contexts.

Keywords: Electronic banking, Customer satisfaction, Limpopo province, Internet, Banking

\section{Introduction}

Changing consumer needs, innovative financial products, changes in the industry structure and a mix of delivery channels are reshaping the banking industry in South Africa. An important factor and enabler in this process of fast-pace change and innovation is the Internet. The Internet has revolutionised the banking sector by offering customers additional functionality, 24-hour access to their money as well as time and cost savings. The Internet dissolves traditional boundaries between financial institutions and empowers individuals to choose and define their own financial futures. One of the effects of this new freedom is a growing convergence in the financial services industry, whereby traditionally specialized organizations are now offering financial services that cross all sections of the population. This means that traditional banks are fast losing their key differentiating characteristics. A great challenge, therefore, is to refocus their attention on their customers and gain a financial services perspective. This has forced banks to look at their internal procedures in order to cope with the fast-evolving needs and expectations of their customers. The aim of this research was to determine the perceptions of electronic-banking services by clients in selected areas of Polokwane, Makhado, Musina, Thohoyandou, and Bochum in the Limpopo Province of South Africa.

Although some South African banks have undertaken their own studies, these were frequently focused on particular aspects and were often driven by various strategic and (internal) political objectives. In addition, the results of those studies were not commonly made public. Finally, those studies were often commissioned by individual institutions and fail to represent an industry-wide picture. Therefore, this study sought to make up for this gap. It is important therefore, to realize that the South African situation differs fairly dramatically from that in other countries due to its very 
specific industrial configuration and regulations, population characteristics, banking information technologies and Internet infrastructure. Thus, the results from international studies are not likely to be usable in a South African context. However, it is common sense that we can draw parallels from the results of these studies and learn more about how to address the perceptual problems of South African banking clients.

South Africa has a significantly large population, who are mainly located in the rural areas. Seemingly, these bank clients have received very little and varied information about the provision of electronic-banking services. The reason being that recent online messages gave security scares to most clients. The study hypothesized that this could be the result of a low level of education, the poor infrastructure, the socio-economic environment.

\section{AIM of the Study}

The study aimed to investigate the perceptions of bank clients on electronic-banking services in the Limpopo Province of South Africa and to suggest strategies to banks to make clients more aware of the electronic-banking services they provide.

\section{Objectives}

- To explore the perceptions of clients on e-banking services in Limpopo Province.

- To examine the role and importance of electronic-banking in the Limpopo Province.

- To determine if banks are educating clients on the benefits and uses of electronic banking and encouraging the use of electronic banking products.

- To investigate if there are other factors beyond banks' control that affect the perception of clients on electronicbanking.

\section{Research Questions}

To achieve the above mentioned aim and objectives the study sought to answer the following research questions:

- What are the perceptions of clients on electronic-banking services in the Limpopo Province?

- What is the relative importance of internet banking service that customers are satisfied or dissatisfied with?

- Does e-banking make the banking transactions easier?

- Is e-banking reliable and credible when making transactions?

\section{Hypothesis}

Ultimately the study sought to test the following hypothesis with regards to the perceptions of bank clients towards electronic banking:

Ho Bank clients have negative perceptions towards electronic-banking services provided by their banks.

$\mathrm{Ha}$ Bank clients have positive perceptions towards e-banking services provided by their banks.

\section{Review of Literature}

The internet is transforming the banking and financial industry in terms of the nature of core products/services and the way these are packaged, proposed, delivered, and consumed (Sathye, 1999). It is an invaluable and powerful tool driving development, supporting growth, promoting innovation, and enhancing competitiveness (Kamel, 2005 and Nath, Shrick \& Parzinger, 2001). Banks and other businesses alike are turning to Information Technology (IT) to improve business efficiency, service quality and attract new customers (Nath et al. 2001 and Kannabira \& Narayan, 2005). Goi (2005), states that technological innovations have been identified to contribute to the distribution channels of banks and, therefore, these electronic delivery channels are collectively referred to as electronic banking. The evolution of banking technology has been driven by changes in distribution channels as evidenced by devices such as Automated Teller Machine (ATM), Phone- banking, Tele-banking, PC-banking and most recently Internet banking (Chang, 2003 and Gallup Consulting, 2008).

Many banks are turning to self-service technologies to provide their customers with many channels to access their products and services. Internet and cell phones are some of the least costly and increasingly very popular financial 
service delivery channels. In developing countries though, the level of information and communication technology development, the cost of the internet and the limited bandwidth of mobile networks and other access technologies may be elements that may constrain such innovation.

\subsection{Overview of E-banking}

According to Network User Address (NUA) internet surveys (www.nua.ie.com), there are over 620 million people linked to the Internet worldwide. The site also provided experts' estimations that the net usage tripled by 2006 and that by 2010,47 $\%$ of business would be online. Any visionary company would obviously want a share of this market. However, more and more companies who joined the internet bandwagon have realized that the success of the early days of the internet, "Build it and they shall come" is not true. Beyond the obvious needs for the marketing and promotion of a site, executives who are responsible for their site's success are increasingly realizing that they need a creative tactic as a magnet to draw and retain customers. In short, the battle is raging in the online war for the hearts, minds and purses of customers, and that needs innovative strategies and tactics to win such a battle. If one does not identify the best strategies, the competitors' will. The motive for attracting customers is very obvious, financial gain.

\subsection{E-Commerce Defined}

Laudon and Laudon (1998:312) express the concept e-commerce as: "... the process of buying and selling goods electronically". Papazoglou and Ribbers (2006:2) proclaim that electronic-business is the conduct of automated business transactions by means of electronic communication networks (e.g. via the internet) end-to-end. Barnes and Hunt (2001: ix) refer to electronic-commerce as: "... transactions taking place over electronic networks". E-banking is the abbreviation for electronic banking. It can also be called digital banking, internet banking and online finance transactions. According to e-commerce@its.best.uk (www.e-commerce@its.best.uk), it is the automated delivery of new and traditional products and services directly to customers through electronic, interactive communication channels. It includes allowing customers access to accounts, and getting information on services through public and private networks including the internet (www.e-commerce@its.best.uk). Telnet banking is also a development of electronic-banking. This allows banking through the telephone and internet. Mobile banking is another addition to electronic-banking. It involves offering banking products through devices such as mobile phones (cell phones) (Chaffey, Mayer, Johnston \& Chadwick, 2003:25, 102).

\subsection{Benefits of Electronic-banking}

There are many benefits of introducing e-banking to the different stakeholders, hence many companies have joined the bandwagon s to enjoy these benefits. Below are some benefits of e-banking to the customers, firms and regulators who are the most important stakeholders in this research.

- Customers:The traditional way of doing banking applications for any client or customer is associated with problems of long queues and long waiting periods. Contrary to this, electronic-banking provides easy access for the account holder to their account to perform banking transactions successfully. Thus, any banking requirement can be managed easily online. The services are not limited to working hours or bank holidays. It is available all the time 24/7 (Guide to Online Banking, 2003).

According to Greenstein and Feinman (2000:4,5), customers may expect to receive an increased choice of vendors and products, convenience from shopping at home or the office, greater amounts of information that can be accessed on demand, more competitive prices and increased price comparison capabilities, and greater customization in the delivery of services. A customer is free to demand 24 hours banking services, unlike the traditional 8 hours.

- Banks : On the bankers' side, with the increase in demand for high wages worldwide, there is great cost reduction i.e. fixed and variable. The savings from the overheads reflect positively in the competitive nature of the service or product the bank offers. It can be reflected in low interest rates, producing sensible personal loans and good offerings in respect of loans and mortgages (Sprecher, 2009, Guide to online banking, www.helium.com and Internet Banking - An Overview, www.uob.com). According to ecommerce@its.best.com, (www.E-commerce@its.best.uk), the key advantage of electronic-banking is increased convenience and functionality and customer satisfaction. According to Chaffey et al. (2003:14), the chief benefit of electronic-business is that it brings customer focus to the business. It makes the business keep customers loyal, anticipate future needs, respond to customer concerns and provides top quality customer 
service. In electronic-business quality and not price becomes the primary determinant in customers' perception of value.

There is more choice for the customer. This is choice on time to demand the service, the service option and the firm to get service from. At the same time, the customer has many service providers who include service providers from outside the domestic market. S/he can choose service from other countries' service providers instead of locking her/himself to local service providers (Sergeant, 2000). O'Brien (2001) mentions that, the chief benefit of e-business is that it brings customer focus to the business. It makes the business keep customers loyal, anticipate future needs, respond to customer concerns and provide top quality customer service. In e-business, quality, not prices, becomes the primary determinant in the customer's perception of value. It has become a strategic opportunity for companies to offer fast, responsive, high quality products, and services tailored to customer preferences.

\section{Research Methodology}

A quantitative methodology abstracts data from the participants into statistical representations rather than textual pictures of the phenomenon. The entire research process is objectively constructed and the findings are usually representative of the population being studied. The quantitative approach has its own limitations. Its mechanistic ethos tends to exclude notions of freedom, choice and moral responsibility. Quantification can become an end in itself rather than a human endeavour seeking to explore the human condition. It fails to take account of peoples' unique ability to interpret their experiences, construct their own meanings and act on these. The main strengths of the quantitative approach lie in precision and control. Control is achieved through the sampling and design, and precise and reliable quantitative measurement.

\subsection{Measuring Instrument}

Survey research designs can be classified into three types, namely: descriptive research design, exploratory research design and causal research design. However, for the purpose of this study, only the descriptive and exploratory research designs were relevant. To satisfy the information needs of any study or research project, an appropriate methodology was selected and suitable tools for data collection (and analysis) were employed (Mouton, 2001).

This study employed a descriptive survey as the main research design. The study utilised the descriptive survey as it was suitable for allowing the respondents to express their feelings with regard to electronic-banking. In addition, the descriptive survey was used for data collection on opinions, perceptions and attitudes of respondents towards the causes of low interest in electronic-banking. The study required data that were primary and collected from original respondents through questionnaires. Data were also collected from bank managers and customers. In addition, the study utilises the descriptive survey design because it enabled him to systematically describe the perceptions of bank managers and customers on electronic-banking.

\subsection{Population and Sample}

Thus, this study viewed a population as any group of individuals that have one or more characteristics in common that are of interest to the study. In this case, the population of the study was the bank clients and bank managers. However, it was clear that the participants of this study were too many to handle. As a result, to select a manageable group, the study resorted to sampling. Best and Khan (1995:13) defines a sample as a small proportion of a population selected for observation and analysis. By observing the characteristics of the sample, one can make certain inferences about the characteristics of the population from which it is drawn. Tustin, Ligthelm, Martins and Van Wyk (2003:337) define a sample as a subset of a population (universe). Within this context a population is defined as the total group of people or entities from which information is required. The main purpose of sampling in respect of this study was to achieve representativeness of the perceptions of banking clients in the Limpopo Province towards e-banking services. The sample was assembled in a way to be representative of the population from which it was taken. To achieve this, the sampling units were randomly selected. This is the most post popular way to sampling, but it is by no means the only one, nor is representativeness - in a numerical sense - the only aim of sampling procedures.

\subsection{Sampling Procedure}

The target population is the aggregate of all elements from which the sample is drawn. Martins (1995:252) explains: "... it 
is that part of the population on which the study is based". Oppenheim (1992:196) defines target population as the population of interest to the researcher. Consequently, in this study, the researcher targeted 279 respondents consisting of 47 bank managers and 232 customers. From the 232 customers, the following age groups from each bank were selected for interviews - five, 20 to 35 years; five, 3645 years; five, 46 to 55 years; five, above 56 . The respondents were drawn from all the commercial banks in the Limpopo Province.

To have a fair representation, purposive samples of different bank groups, operating in the Limpopo Province, were selected. For this study, the researcher purposively selected banks in Polokwane, Makhado, Thohoyandou, Musina, and Bochum where he believed that these areas provided a representative distribution of the bank clients of the Limpopo Province. Table 1 below provides a breakdown of branches in each study area as provided by managers in Polokwane of each bank operating in the Limpopo Province.

Table 1: Breakdown of branches in each study area

\begin{tabular}{|c|c|c|c|c|c|c|c|}
\hline Area & FNB & Standard Bank & ABSA & NEDBANK & Capitec Bank & African Bank & Branch Total \\
\hline Polokwane & 5 & 6 & 5 & 5 & 4 & 3 & $\mathbf{2 8}$ \\
\hline Makhado & 1 & 1 & 1 & 2 & 2 & 1 & $\mathbf{8}$ \\
\hline Thohoyandou & 1 & 2 & 1 & 2 & 3 & 1 & 10 \\
\hline Musina & 1 & 1 & 1 & 1 & 1 & - & $\mathbf{5}$ \\
\hline Bochum & 1 & 1 & 1 & 1 & - & 1 & $\mathbf{5}$ \\
\hline Total & 9 & 11 & 9 & 11 & 10 & $\mathbf{6}$ & $\mathbf{5 6}$ \\
\hline
\end{tabular}

Bank branches within Polokwane included in the sample were selected using stratified sampling. Those branches outside Polokwane with one branch in a study area were automatically selected. If a bank outside Polokwane had more than one branch, one branch was selected using purposive or convenient sampling. A breakdown of those who were interviewed in the study is shown in Table 2 below.

Table 2:Breakdown of managers in each study area to be interviewed

\begin{tabular}{|c|c|c|c|c|c|c|c|}
\hline Area & FNB & Standard Bank & ABSA & NEDBANK & Capitec Bank & African Bank & Branch Totals \\
\hline Polokwane & 5 & 5 & 5 & 5 & 3 & 3 & 26 \\
\hline Makhado & 1 & 1 & 1 & 1 & 1 & - & 5 \\
\hline Thohoyandou & 1 & 1 & 1 & 1 & 1 & 1 & 6 \\
\hline Musina & 1 & 1 & 1 & 1 & 1 & - & 5 \\
\hline Bochum & 1 & 1 & 1 & 1 & - & 1 & 5 \\
\hline Total & 9 & 9 & 9 & 9 & 6 & 5 & 47 \\
\hline
\end{tabular}

The total sample size of $N=47$ was selected as follows:

First, a stratified sample of size 26 was selected within Polokwane, each of the 6 banks was considered as a stratum. The sample size of 26 was obtained on the basis of a margin error of 5\% and a confidence level of $95 \%$ and population size of 28 (Talent Management Solutions at www.custominsight.com/articles/random-sample-calculator.asp).

The sample size within each bank in Polokwane was calculated using the following proportionate stratification formula: $n_{h}=\frac{N_{h}}{N} \times n$

Where: $n_{h}$ is the number of branches sampled in each bank.

$N_{h}$ is the total number of branches within each bank.

$\mathrm{N}$ is the total number of bank branches within Polokwane.

$\mathrm{n}$ is the total number of bank branches sampled within Polokwane.

For example, for FNB bank $n_{F N B}=\frac{5}{28} \times 26 n_{F N B} \cong 5$

This same formula was applied to the rest of the banks to obtain the numbers in row two of Table 2.

Bank managers could not provide the total number of clients per branch. The number of branches each bank had in each study area/location was used to calculate the number of clients to interview, hence the use of stratified sampling in order to force a fair representation. Table 3 below shows the calculation for clients for each bank branch in the study area to be interviewed. 
Table 3: Breakdown of clients for each bank branch in the study area to be interviewed

\begin{tabular}{|c|c|c|c|c|c|c|c|}
\hline Area & FNB & Standard Bank & ABSA & NEDBANK & Capitec Bank & African Bank & Branch Totals \\
\hline Polokwane & 12 & 18 & 12 & 18 & 13 & 12 & 85 \\
\hline Makhado & 7 & 7 & 7 & 7 & 7 & - & 35 \\
\hline Thohoyandou & 7 & 7 & 7 & 7 & 7 & 7 & 42 \\
\hline Musina & 7 & 7 & 7 & 7 & 7 & - & 35 \\
\hline Bochum & 7 & 7 & 7 & 7 & - & 7 & 35 \\
\hline Total & 40 & 46 & 40 & 46 & 34 & 26 & 232 \\
\hline
\end{tabular}

The calculation of the above table is as follows:

Total number of branches in a study area $\times$ Total clients targeted to be interviewed

Total number of branches per bank in an area

For example for FNB $=\underline{12} \times 406=13.33$ (13 to nearest)

In all areas studied with one bank branch as shown in Table 2, 7 clients were interviewed.

Furthermore, a convenient sample of 232 customers from banks included in the sample was interviewed. In the areas where bank managers were interviewed, customers for each bank manager interviewed in a specific area were conveniently selected and interviewed. Therefore, from table 3.3 above, 40 customers from FNB, 46 from Standard Bank, 40 from ABSA, 46 from Nedbank, 34 from Capitec, and 26 from African bank, were interviewed.

\subsection{Data Collection}

A questionnaire is, according to Tustin, et al. (2003:385), simply a data-collection (research) instrument that sets out the questions to be asked in a formal way in order to produce the desired information. The questionnaire was used ahead of other means of data gathering because it had the advantage of reaching many respondents. It was cheaper and more convenient to distribute. It could be distributed quicker, thus, saving time. A questionnaire was designed for both bank clients and bank managers. The structure of the questionnaire comprised mainly close-ended questions. Close-ended questions restrict respondents in their answers. However, close-ended questions have proved easier to analyse, and thus more suitable for projects with strict time limits and financial resources such as this one. A Likert scale questionnaire survey was the main instrument providing quantitative data, and was designed around opinion statements as a means of exploring respondents' perceptions of electronic-banking. Questionnaire household surveys using the Likert scale have been used widely by other researchers.

\subsubsection{Secondary Data Collection}

Secondary research is research based on secondary resources that already exist (Bryman, 1995:83). Secondary research methods in this research included journals, World Wide Web (internet), newspapers, magazine articles, government publications, books, expert contacts, unpublished manuscripts, and reports.

\subsection{Data Analysis}

Data from questionnaires were analysed as follows: editing, error checking and data input. Techniques such as tables, bar graphs, histograms, and graphic illustrations were used to present the results. Statistical Product and Service Solutions (SPSS) was also used to analyse data obtained from the questionnaires and in this case, T testing was used to correlate data from those who knew about the availability of electronic-banking services and those who did not know about it. The T-Test was chosen because it is a tool that can easily compare data from two cells. The assistance of a statistician was used to assist in analysing the collected data.

\section{Summary of Results}

\subsection{Respondents' Demographics}

The demographic characteristics of the respondents who participated in this study are reflected in Figures 1-4. 


\subsubsection{Respondents' gender}

The results of this study show that $47 \%$ of the respondents were males and 53\%were females as reflected in Figure 1. This is an interesting observation in e-banking, because it reveals that the majority of e-bankers are women. This study also observed that more female bankers are concerned about security issues as compared to their male counterparts who were less concerned.

Figure 1: Respondents by Gender.

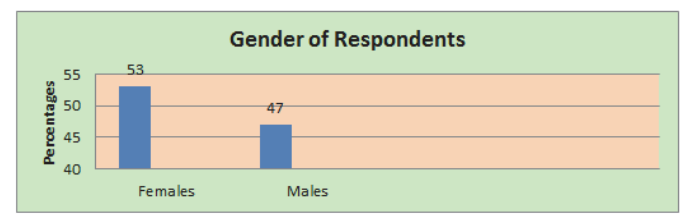

Source: Author's Field Data, 2012.

\subsubsection{Respondents' Age}

Figure 2 below, shows that $35.7 \%$ of the respondents were below the age of 25 years, $33.8 \%$ were between 25 and $35 y e a r s$ and $20.6 \%$ between 36 and 45 years respectively, while $9.9 \%$ were between 46 and 56 years. Overall, this implies that the majority of the respondents were in the economically active population group of $25-45$ years.

Figure 2: Respondents by age.

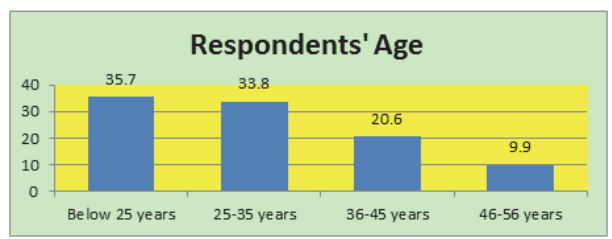

Source: Author's Field Data, 2012.

Figure 3 indicates that all the respondents were educated. The majority (75.3\%) had tertiary education, while $7.8 \%$ had Senior High School (SHS) and 16.9\% had post-SHS education.

Figure 3: Level of education of the respondents.

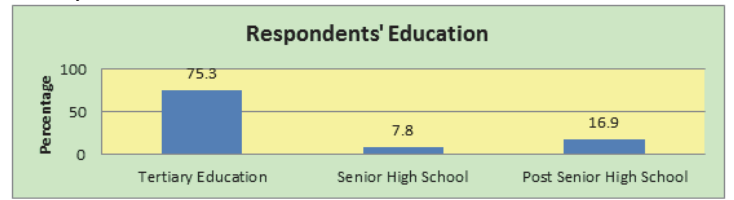

Source: Author's Field Data, 2012.

\subsubsection{Respondents' income}

Figure 4 summarises the income situation of the participants per month. In terms of monthly income, $29.9 \%$ of the participants earned less than R3, 000 per month, 38.8\% earned between R3, 001-R6, 000 per month, while 23.2\% earned between R6001 to R10, 000 per month. 8.1\% of the respondents earned more than R10, 000 per month.

Figure 4: Monthly income of the respondents.

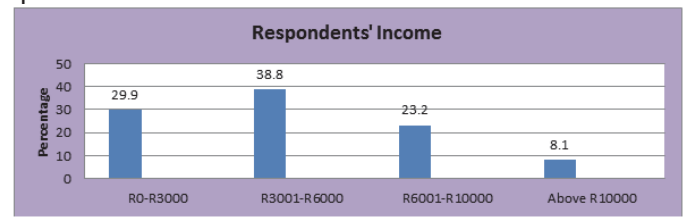

Source: Author's Field Data, 2012. 


\subsubsection{Respondents' marital status}

Figure 5 reflects the marital status of the respondents. The results show that $70.1 \%$ of the participants were married, $28.6 \%$ were single and $1.3 \%$ had another marital status.

Figure 5: Marital status of the respondents.

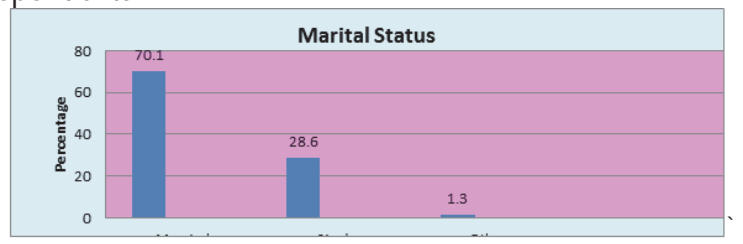

Source: Author's Field Data, 2012.

\subsection{Summary of respondents' data characteristics}

A summary of the respondents' demographic characteristics depicts a fairly balanced gender distribution; most of the respondents were females banking with different banks in the Limpopo Province. It also depicts that the majority of the respondents were in the economically active population ( $25-45$ years). Most of the respondents were educated with the majority of them having tertiary or higher education. Most of the respondents' income was belowR3, 900 per month which could be described as considerably low. In terms of marital status, most of the respondents were married. Single persons represented a relatively small percentage, while other forms of marriage were insignificant.

\subsection{Influence of E-banking services Variables on Overall Satisfaction}

Table 4: Multiple Regression Summary

\begin{tabular}{|l|l|c|c|}
\hline \multicolumn{1}{|c|}{ Multiple Regression Summary } & \multicolumn{2}{c|}{ Standardised coefficient } \\
\hline \multicolumn{1}{|c|}{ Variables } & Bank managers & General customers \\
\hline Label & \multicolumn{1}{|c|}{ - } & .302 & .260 \\
\hline WD1 & Easy completion of online transactions. & -.089 & .175 \\
WD2 & Easy logging on online portal & -.090 & -.244 \\
\hline WD3 & Easy understanding which button to be clicked for the next step. & .357 & .282 \\
\hline WD4 & Ability of this internet portal in helping customer to complete a transaction quickly. & .307 \\
\hline CS1 & Sufficient and real time financial information provided by the internet banking portal site. & .205 & -.035 \\
\hline CS2 & Validity of the hyperlinks on the bank's portal. & -.107 & .064 \\
\hline CS3 & Speed of the Web page on bank's portal site loading. & .010 & .225 \\
\hline CS4 & Ability of the bank's banking portal to perform service correctly at the first time. & .188 & .056 \\
\hline CS5 & Prompt reception of responses to customer request. & .056 & -.106 \\
\hline CS6 & Internet banking system's ability to guide customer to resolve problems. & -.077 & -.046 \\
\hline AS1 & Reliability and credibility of transactions on the banking portal. & .000 & .109 \\
\hline AS2 & Protection/security of customer transaction data by the banking portal site. & .195 & -.023 \\
\hline AS3 & Feeling of relief of customer to transact on internet banking. & -.082 & .186 \\
\hline PT1 & Offering preferentially lower fees/ rates and charges. & -.064 & .024 \\
\hline PT2 & Reasonability of the transaction fee for this banking portal site. & .199 & .030 \\
\hline IP1 & Complete and sufficiency of the information the internet banking portal provides. & .070 & -.066 \\
\hline IP2 & Accuracy of the online transaction process of the bank. & -.120 \\
\hline
\end{tabular}

Source: Author's Field Data, 2012.

Table 4 depicts a regression model showing the impact of 17 variables of e-banking on overall customer satisfaction (OCS) for customers and bank managers. In the model, for customers, only two variables significantly affect OCS ( $p$ > 0.05); these are easy completion of online transactions (WD1) and ability of the internet portal in helping customer to complete a transaction quickly (WD4). For bank managers or bank staff, only four variables significantly affect OCS at 0.05. These variables are easy completion of online transactions (WD1), easy understanding which button to be clicked for the next step (WD3), ability of this internet portal in helping customers to complete a transaction quickly(WD4), and sufficient and real time financial information provided by the internet banking portal site(CS1). 
The overall model estimates for customers using the online services is significant $(F=9.104$, df $=17$,sig. $=0.000)$ and for bank managers the overall model is significant $(F=10.062$, df $=17$, sig. $=0.000)$. The implication is all the variables collectively impact OCS, but individually only a few significantly impact OCS.

\subsection{Discussion of Results}

The following discussion is done in the light of the research questions set for this study. It analyses both within and crosscase analysis of the respondents from different educational, income cum occupational categories.

\subsubsection{Perceptions of customer satisfaction with regard to e-banking services in the Limpopo Province}

For the purpose of clarity in describing customer satisfaction for each dimension item within and between the cases, dissatisfaction would be described by adding ratings for much worse than expected (1) and worse than expected (2), while satisfaction would be described by adding ratings for equal to (3), better than (4) and much better than expected (5). Satisfaction with ease of completing of online transactions (WD1) could be described as high since only 13\% indicated that they are not satisfied while the rest (87\%) maintained that they are satisfied. For ease in logging on bank's online portal (WD2), only 16.9\% were dissatisfied while the rest (83.1\%) were satisfied, so satisfaction could be described as high for this dimension. For ease of understanding which button to be clicked for the next step (WD3), only 13\% were dissatisfied while the majority (87\%)were satisfied, so customers could be said to be more satisfied for this item. Regarding, the ability of the internet portal in helping customers to complete a transaction quickly (WD4) $22.10 \%$ of customers were dissatisfied while $77.90 \%$ were satisfied, therefore generally the customers are more satisfied with this dimension item than dissatisfied.

For customer service factor (CS1), being sufficiency of and real time financial information provided by the internet banking portal site, $15.60 \%$ of the respondents were dissatisfied while $84.40 \%$ were satisfied, which could be described as high satisfaction for this item. Regarding the validity of the hyperlinks on the bank's portal (CS2), customers were more satisfied since only $11.70 \%$ of them were dissatisfied while $88.30 \%$ were satisfied. For the quickness of the Web page on the bank's portal site loading (CS3), customers were more dissatisfied than satisfied since $78.00 \%$ were dissatisfied while only $22.00 \%$ were satisfied. For the ability of the bank's banking portal to perform service correctly at the first time (CS4), more customers were satisfied (81.80\%) than dissatisfied (18.20\%).For prompt reception of responses to customer requests (CS5), customers were more dissatisfied (84.50\%) than they were satisfied (15.50\%). Finally, for the last customer service factor, being the internet banking system's ability to guide customers to resolve problems (CS6), more customers were dissatisfied (84.50\%) than satisfied (15.50\%).

Regarding the assurance factor which is the reliability and credibility of transactions on the banking portal (AS1) received less dissatisfaction rating (15.60\%) than satisfaction rating(84.40\%).For protection/security of customer transaction data by the banking portal site (AS2), more of the customers were satisfied (92.20\%) than dissatisfied (7.80\%). For AS3, which is the feeling of relief of customers to transact on internet banking, more customers were satisfied (98.70\%) than dissatisfied (1.30\%).

Moreover, for the first preferential treatment dimension which is offering preferentially lower fees/rates and charges (PT1), more customers were dissatisfied (68.80\%) than satisfied (31.20\%). For reasonability of the transaction fee for this banking portal site (PT2), apparently more customers were dissatisfied (89.60\%) than satisfied (10.40\%). Finally, for both information provision dimensions which are the provision of complete and sufficiency of the information, the internet banking portal provides (IP1) and accuracy of the online transaction process of the bank (IP2), customers were more satisfied (97.40\% and $98.70 \%$ respectively) than dissatisfied (2.60\%and $1.30 \%)$ respectively.

Table 5: Summary of the main points of discussion for GCB

\begin{tabular}{|l|l|c|c|c|}
\hline \multicolumn{1}{|c|}{ Dimension items } & \multicolumn{2}{|c|}{ CUSTOMERS } & \multirow{2}{*}{ Remarks } \\
\cline { 3 - 5 } & \multicolumn{1}{|c|}{ dissatisfied } & Satisfied & \\
\hline WD1 & Easy completion of online transactions. & $13 \%$ & $87 \%$ & More satisfied \\
\hline WD2 & Easy logging on online portal. & $16.90 \%$ & $83.10 \%$ & More satisfied \\
\hline WD3 & Easy understanding which button to be clicked for the next step. & $13 \%$ & $87 \%$ & More satisfied \\
\hline WD4 & Ability of this internet portal in helping customer to complete a transaction quickly. & $22.10 \%$ & $77.90 \%$ & More satisfied \\
\hline CS1 & Sufficient and real time financial information provided by the internet banking portal site. & $15.60 \%$ & $84.40 \%$ & More satisfied \\
\hline CS2 & Validity of the hyperlinks on the bank's portal. & $11.70 \%$ & $88.30 \%$ & More satisfied \\
\hline CS3 & Quickness of the Webpage on bank's portal site loading. & $78.00 \%$ & $22.00 \%$ & More dissatisfied \\
\hline
\end{tabular}




\begin{tabular}{|l|l|c|c|c|}
\hline CS4 & Ability of the bank's banking portal to perform service correctly at the first time. & $18.20 \%$ & $81.80 \%$ & More satisfied \\
\hline CS5 & Prompt reception of responses to customer request. & $84.50 \%$ & $15.50 \%$ & More dissatisfied \\
\hline CS6 & Internet banking system's ability to guide customer to resolve problems. & $84.50 \%$ & $15.50 \%$ & More dissatisfied \\
\hline AS1 & Reliability and credibility of transactions on the banking portal. & $15.60 \%$ & $84.40 \%$ & More satisfied \\
\hline AS2 & Protection/security of customer transaction data by the banking portal site. & $7.80 \%$ & $92.20 \%$ & More satisfied \\
\hline AS3 & Feeling of relief of customer to transact on internet banking. & $1.30 \%$ & $98.70 \%$ & More satisfied \\
\hline PT1 & Offering preferentially lower fees/ rates and charges. & $68.80 \%$ & $31.20 \%$ & More dissatisfied \\
\hline PT2 & Reasonability of the transaction fee for this banking portal site. & $89.60 \%$ & $10.40 \%$ & More dissatisfied \\
\hline IP1 & $\begin{array}{l}\text { Complete and sufficiency of the } \\
\text { information the internet banking portal provides. }\end{array}$ & $2.60 \%$ & $97.40 \%$ & More satisfied \\
\hline IP2 & Accuracy of the online transaction process of the bank. & $1.30 \%$ & $98.70 \%$ & More satisfied \\
\hline
\end{tabular}

Source: Author's Field Data, 2012.

Significantly, it could be deduced from the discussion summarized that out of the 17 dimension items, fewer customers were dissatisfied with the five dimension items while most of the respondents were satisfied with the rest of the 12 dimension items. Out of the five dimension items that customers were dissatisfied with, three are related to customer service:

- Speed of the Webpage on bank's portal site loading.

- Prompt reception of responses to customer request.

- Internet banking system's ability to guide customer to resolve problems; and two are related to the two items of preferential treatment.

- Offering preferentially lower fees/rates and charges.

- Reasonability of the transaction fee for the banking portal site.

In the survey undertaken, more customers were satisfied than dissatisfied. However, for five dimension items, between $30 \%$ and $40 \%$ of the customers were dissatisfied, which needs to be noted by management of the banks. These five dimensions included three items related to customer service, which are:

- Speed of the Web page on bank's portal site loading.

- Prompt reception of responses to customer requests.

- Internet banking system's ability to guide customers to resolve problems; and two are related to the two items of preferential treatment.

- Offering preferentially lower fees/rates and charges.

- Reasonability of the transaction fee for this banking portal site.

\subsubsection{Cross-case analysis of the banks in Limpopo Province used by customers for internet banking}

Comparing customer satisfaction relating toe-banking services in the banks in the Limpopo Province, some significant patterns could be drawn. First of all, on their similarities, most customers of all the banks indicated that they were satisfied with all factors in e-banking, all information provision items, and all three assurance items of the e-banking services provided. Secondly, the five factors that received considerable dissatisfaction ratings (between 30\% and 40\%) were the same factors for bank customers and non-bank customers.

On the differences in satisfaction for the 17 dimension items of e-banking services, the customers were usually dissatisfied with five dimension items and satisfied with 12 items, the customers were typically satisfied with all the dimension items.

Thus, customers from different income and educational backgrounds do have something in common though there are places/instances where they differ. The banks exhibit similar characteristics regarding their satisfaction and dissatisfaction with the dimensions of e-banking services.

\subsubsection{What is the relative importance of internet banking services that customers are satisfied or dissatisfied with?}

A careful study of the empirical results presented in the table 4.4reveals significant patterns in the relative importance of customer satisfaction of e-banking services for all the banks. This is discussed in the following sections below.

\subsubsection{Influence of e-banking variables on Overall Satisfaction}

The implication is that all the variables collectively impact OCS, but individually only a few significantly impact OCS. 
More specifically, the regression shows that out of the 17 variables of e-banking, only two variables significantly affect OCS ( $p>0.05)$; namely: easy completion of online transactions (WD1)and ability of the internet portal in helping customer to complete a transaction quickly (WD4). Again, only four variables significantly affect OCS, namely: easy completion of online transactions (WD1), easy understanding which button to be clicked for the next step (WD3), ability of this internet portal in helping customer to complete a transaction quickly(WD4), and sufficient and real time financial information provided by the internet banking portal site(CS1). Thus, only two main variables: Easy completion of online transactions (WD1)and ability of the internet portal in helping customer to complete a transaction quickly (WD4), are common e-banking service variables that are found to have significant influence in respect of all the banks in the Limpopo Province. These finding are consistent with many other studies such as Rod, Ashill, Shao and Carruthers (2009) who found, among others, that web design factors are strong predictors of customer satisfaction. In a UK context, Jayawardhena and Foley (2000b) found that web site features such as speed, web site content and design, navigation, interactivity and security all influence user satisfaction.

\subsubsection{Demographic differences in Overall Satisfaction}

According to Table 2, generally, differences in satisfaction of e-banking services significantly differ among only income groups, but not significantly according to gender, education, income, and marital status. The results further suggest that respondents who earn between R6001 - R10 000 are more satisfied than those in the lowest and highest income groups. Since customer satisfaction with e-banking services differs according to income, it implies that income could be an important predictor of customer satisfaction and that the management of the banks could develop internet banking services to suit different income groups. It is important to note that in a developing country such as South Africa, where the per capita income is medium, consumers are always price conscious because, other things being equal, consumers would desire, prefer and expect the banks to deliver not only quality internet banking services, but also, and more importantly, affordable internet banking services since their income rotates in the medium scale.

\section{Implications of the Study, Conclusion and Recommendations}

\subsection{Summary of Study}

The main purpose of this study was to investigate the perceptions of customers on e-banking services in the Limpopo Province of South Africa. The respondents were drawn from the banks in the Limpopo Province, namely ABSA, Nedbank, FNB, Capitec, and Standard Bank. To be specific, the study sought to evaluate customer perceptions, that is, satisfaction/dissatisfaction regarding several dimensions of e-banking services in South Africa. Methodologically, the study was a cross-sectional case survey that involved the use of a self-administered structured questionnaire to collect primary data from the respondents who use internet banking in the Limpopo Province. Two hundred and fifty (250) questionnaires were distributed to the respondents. Data were analysed using the SPSS 16.0.

\subsection{The Theoretical Implications of the Study}

The study observed that many previous studies have examined customer satisfaction with e-banking services. This study contributes to the global body of knowledge in the area of customer's perceptions of e-banking services by examining the phenomenon in the context of banks in the Limpopo Province of South Africa. The study found that the assurance for online security is the most important e-banking services item, namely, relief of customer to transact on e-banking. This contradicts the finding of Rod, et al. (2009), who found that assurance of the dimensions could be dropped since it was not a significant quality dimension in e-banking, which they defined differently to mean the knowledge and courtesy of administrators.

In addition to that, the study showed that customer satisfaction and its relative importance may significantly differ from one e-banking service provider to the other in the same context. Similarly, it has particularly provided insight into the effect of e-banking services on overall user satisfaction. It provides evidence that the provision of superior customer service and the giving of preferential rates for online services are two most important factors that could influence user satisfaction with e-banking services in South Africa. This could be an area for further and future research agendas for scholars and practitioners. This study, again, increases the extent of knowledge on the subject of customer satisfaction with e-banking services in the Limpopo Province, which has not received much attention in academic literature (Abor, 2004; Gyasi \& Azumah, 2009). Furthermore, the study contributes to the literature on the differences in satisfaction based 
on consumer demographic variables such as gender, age, income, education, and marital status. It highlights the significant demographic variables, such as income, that are likely to influence customer satisfaction regarding e-banking services in developing countries.

\section{Implications for Banking Service Providers, Management and Recommendations}

\subsection{Prevent potential and existing customer switching}

The difference in customer overall evaluation of e-banking services for different banks has important implications for bank management. It implies that since the internet banking services meet customers' expectations more in other banks, it can lead to potential and actual customers switching to those banks which offer better e-banking services as more and more customers talk about their dissatisfaction with other banks' e-banking services. A number of studies have shown that verbal communication has the potential of, not only, discouraging other customers from patronizing a product/service but also has the ability to attract new customer to a superior service provider (Blodgett et al. 1995; Bougie, Pieters \& Zeelenberg, 2003; Jones, McCleary \& Lepisto, 2002; Singh \& Wilkes, 1996). As a result, it is recommended that to prevent customer switching from one bank to another, the management of banks need to ensure that, their e-banking services meet and exceed customers' expectations.

\subsection{The influence of customer satisfaction through web page design}

i) Because the study found two most important factors that significantly influence overall customer satisfaction, the management of a bank could influence customer overall satisfaction by focusing attention on these two items, which are: easy completion of online transactions (WD1); and

ii) ability of the internet portal in helping customers to complete a transaction quickly (WD4).

These two factors are both web design factors. Management needs to keep improving upon the web design of the internet banking portal to make it user friendly and also in order to avoid wasting the customers' time for online transactions as a result of web page design.

\subsection{Reduce customer dissatisfaction through customer service and affordable online charges}

Since the study found that more customers were dissatisfied with five dimension items, three of which are related to customer service and two related to preferential treatment for online charges, it is recommended that bank management focuses attention on improving the following important quality items for their internet banking services:

- Speed of the Web page on bank's portal site loading: This has to do with the speed of the online system, so management would need to increase the speed or bandwidth for effective browsing and opening of pages; especially, pages with video and pictures require high bandwidth.

- Prompt responses to customer requests: This relates to customer relationship and requires training more responsible and efficient customer service staff that would be able to handle customer requests promptly.

- Internet banking system's ability to guide customers to resolve problems: Since customers may have many problems in accessing and utilising online banking portals, it is the responsibility of the management to ensure that all diverse customer problems are attended to by technicians with expert knowledge that resolves the problems for customers.

- Offering preferentially lower fees/rates and charges: The results of the study showed that this is very important as customers would expect that with advancement in technology, the cost of online transactions would be moderately cheap to encourage them to continue online banking in an emerging economy such as South Africa. Management should make online banking rates/fees and charges lower to attract more online customers.

- Reasonability of the transaction fee for this banking portal site: This item also relates to the price paid for online banking services. The customers expect to have a reasonable transaction fee. Reasonability is perceived in terms of comparability of the cost benefit analysis of the customer for the overall online banking services. Management should ensure that transaction fees are more reasonable. This could be achieved by involving customers in pricing decisions as this may help reveal many reasonable considerations that customers may expect from the bank regarding online transaction fees. 


\subsection{Focus on customer priority for Assurance and Information Provision}

Since the study showed that customer priority of e-banking services was high for some variables, it implies that management should pay more attention to the e-banking items that received the highest ratings among the customers. In this regard, management should focus and give priority to the following items in providing internet banking services to its customers:

I. Relief of customers to transact on the internet banking portal (AS3). Thus, making customers more relieved to transact business on the internet portal.

II. Accuracy of online transaction and completeness (IP2). Thus, ensuring that online transactions are free from mistakes and errors.

III. Sufficiency of information the internet banking portal provides (IP1). Thus, providing adequate information on the internet banking portal.

\subsection{Segmenting customers based on income earned}

Since the study revealed that satisfaction differences exist among different income groups it implies that customers could be segmented based on distinct income earning groups. Again, it is recommended that management should conduct further studies to gather more information on income differences among their customers. They could have other distinct groups among the customers that could be used as a basis for market segmentation.

\subsection{To the Management of banks providing internet banking in Limpopo Province}

\subsubsection{Use e-banking as competitive advantage}

The difference in customer overall evaluation of e-banking between banks has important implications for management. It implies, that since some have a significantly higher e-banking that meets customers' expectation more than others, it can be used as a competitive tool to attract potential customers. As customers become more and more conscious of their internet banking needs and requirements and which banks to get them from, delivering high quality e-banking could be used to entice potential and/or prospective customers to internet banking services of the bank. One way to attract new customers is by promoting vital marketing among the bank's existing customers. Thus, it is recommended that the management initiates and promotes and sustains vital marketing strategies that ensure that existing customers communicate the e-banking they experience to other prospective online and offline customers. This word-of-mouth communication could attract new customers to a superior service provider (Blodgett et al. 1995; Bougie, Pieters \& Zeelenberg, 2003; Jones, McCleary \& Lepisto, 2002; Singh \& Wilkes, 1996).

\subsubsection{Influence customer satisfaction through web page design and customer service}

Since the study found four most important factors that significantly influence overall customer satisfaction, the management of the bank could influence customer overall satisfaction by focusing attention on the following four items:

I. Easy completion of online transactions (WD1).

II. Easy understanding which button to be clicked for the next step (WD3).

III. Ability of this internet portal in helping customers to complete a transaction quickly (WD4).

IV. Sufficient and real time financial information provided by the internet banking portal site (CS1).

These four factors are web design factors and customer service. Management needs to keep improving upon the web design of the internet banking portal to make it more navigable, provide sufficient and real time information to customers, and make it more easy for customers to complete online transactions and do so as quickly as possible in order to avoid wasting customers' time for online transactions as a result of the web page design.

\subsubsection{Reduce customer dissatisfaction through customer service and preferential online charges}

Although the study found that more customers were satisfied with all the e-banking items, it was noted that some $30 \%$ to $40 \%$ of the customers showed dissatisfaction with five dimension items, three of which are related to customer service and two to preferential treatment for online charges. It is, therefore, recommended to management to focus its attention on these to ensure that there is almost no significant customer dissatisfaction for these important quality items for their 
internet banking services.

\subsubsection{Focus on customer priority for Assurance, Information Provision and Web design}

Since the study showed that customer priority of e-banking services was high for some variables, it implies that management should pay more attention to the e-banking items that received the highest ratings among the customers. In this regard, management should focus on and give priority to the following items in providing internet banking services to its customers:

I. Relief of customer to transact on the portal (AS3).

II. Accuracy of the online transaction process (IP2).

III. Complete and sufficiency of the information provided (IP1).

IV. Protection of customer transaction data (AS2).

V. Reliability and credibility of transactions (AS1).

VI. Ease of completion of online transactions (WD1).

VII. Ease of understanding which button to be clicked for the next step (WD3).

VIII. Sufficient and real time financial information provided (CS1).

\subsubsection{Possible market segmentation based on customer income}

It is also recommended that since the study indicated that satisfaction differences exist among different income groups it means that customers could be segmented based on distinct income earning groups. It is also recommended that management should do further studies to gather more information on income differences among their customers to have other distinct groups among the customers that could be used as a basis for market segmentation.

\section{Conclusions}

The study reviewed literature on the development of e-banking, its challenges, trends, implications and prospects as well as the concepts and theories that have emerged from various scholarly works. Electronic-banking technology has been seen by some researchers as well suited for the financial sector. Some quarters, however, theorise that e-banking cannot stand alone and must be seen to be rather complementary to bricks-and-mortar banking. Thus, the study explored customer perceptions on e-banking. In the process, various conceptions were reviewed. To measure customer satisfaction on online banking services, research questions were developed that sought to identify the perceptions of customers on e-banking. A survey was conducted using questionnaires to collect data from the banks and their customers. The analysis of data followed a statistical descriptive summary of data approach.

\subsection{Implications to Managers}

The study showed that e-banking clearly offers remarkable opportunities to banks in the Limpopo Province. The environment is, however, fraught with challenges which can translate into opportunities given the right approach to strategy. For the competitive bank, e-banking provides a "diamond mine" of customers. Managers must, in addition to a short term strategy, take a long term view of strategy as the internet infrastructure expands. There are already a number of policy initiatives to increase e-banking access across South Africa.

The study recommends that banks must also create an environment that will encourage customers to hook up. A number of potential customers who cannot afford personal computers and internet connectivity should be encouraged to acquire them through special bank loans payable through small monthly deductions from the customer's account. They should first focus on existing bricks-and-mortar bank customers by giving them incentives to go online. On strategic channel focus, banks must leverage the synergy of both traditional and banking channels. For an effective, cost-effective and seamless strategy, the internet should be leveraged so that instead of opening up more physical branches, banks can focus more on virtual branches in the numerous homes and offices of potential customers. The money that will be saved from not putting up physical buildings can be channelled into developing internet infrastructure and service either directly by buying stakes or indirectly by providing loans to the industry.

In conclusion, this study sought to evaluate and describe customer satisfaction with e-banking services of banks in the Limpopo Province in South Africa. Through existing marketing literature and empirical evidence, the study concludes that more customers are satisfied with most dimensions of e-banking services from banks in the Limpopo Province. 
Overall customer satisfaction generally differs between customers from different banks. Relief of customers to transact on the internet banking portal (AS3) appears to be the highest priority of the customers in engaging in online transaction in internet banking in South African online banks. The study also concludes that, collectively e-banking predicts overall customer satisfaction (OCS) in internet banking services of all the banks in the Limpopo Province, and that the two most important common predictors of OCS are the web design factors. These factors are: ease of completion of online transactions; and ability of the internet portal in helping a customer to complete a transaction quickly.

\section{Recommendation for Future Research}

This study was a cross sectional survey, using self-administered questionnaires to collect empirical data. The data were analysed using descriptive and quantitative methods. The work sought to increase the understanding of customer value perceptions in e-banking in the Limpopo Province. Other related areas of research that can be developed from this work, and in the context of the Limpopo Province, were provided. It is recommended that future research could use a different methodology such as the critical incidence technique and focus on extending the study across many similar banks in different countries and in different service contexts.

\section{References}

Abor, J. (2004). Technological innovations and banking in Ghana: An evaluation of customers' perceptions. American Academy of Financial Management, (1), pp1-16.

Barnes, S.\& Hunt, B. (2001).E-Commerce \& V-Business, Business Models for Global Success. London: Butterworth Heinemann.

Best, J.W. \& Khan, J.V. (1995).Research in Education. London: Allyn and Bacon.

Blodgett, J.G., Wakefield, K.L. \& Barnes, J. (1995).The effects of customer service on consumer complaining behaviour. Journal of Services Marketing, 9(4), pp31-42.

Bougie, J.R.G.,Pieters, R.\& Zeelenberg, M. (2003). Angry customers don't come back, they get back: The experience and behavioural implications of anger and dissatisfaction in services. Journal of the Academy of Marketing Science, 31(4), pp377-393.

E-commerce@its.best.uk, (2010). [Online] Available: www.E-commerce@its.best.uk (April 18, 2010).

Chaffey, D., Mayer, R., Johnston, K. \& Chadwick, F. E. (2003).Internet Marketing: Strategy, Implementation and Practice, Boston: Prentice Hall.

Chang Y.T. (2003). Dynamics of Banking Technology Adoption: An Application to Internet Banking, Department of Economics._Workshop Presentation, University of Warwick, Coventry.

Gallup Consulting (2008). Using technology to engage retail banking customers. [Online] Available: http://www.adope.com/engagement. (April 18, 2010).

Greenstein, M. \& Feinman, T. M. (2000).Electronic Commerce: Security, Risk Management and Control, New York: Irwin McGraw-Hill.

Goi, C.L. (2005).E-banking in Malaysia: Opportunities and challenge, Journal of Internet Banking and Commerce, 10(3).

Gyasi, S. N. \& Azumah, K.A. (2009).An Assessment And Analysis of Customer Satisfaction with Service Delivery of Mobile Telecommunication Networks within Ghana,Master's Thesis, LTU, Sweden.

Jayawardhena, C. \& Foley, P. (2000). Changes in the banking sector - the case of Internet banking in the UK. Internet Research: Electronic Networking Applications and Policy, 10(1), pp19-30.

Jones, D.L, McCleary, K.W. \& Lepisto, L.R. (2002). Consumer complaint behavior manifestations for table service restaurants: Identifying sociodemographic characteristics, personality and behavioral factors. Journal of Hospitality \& Tourism Research, 26(2), pp. 105-123.

Kamel, S. (2005).The use of information Technology to Transform the Banking sector in Developing Nations .Information Technology for Development, 11(4), pp305-312.

Kannabira, G. \& Narayan (2005) Deploying internet Banking and e-commerce- Case Study of a Private Sector Bank in India, Information Technology for Development, 11(4), pp 303-318.

Laudon, K. C.\& Laudon, J. P. (1998).Information systems and the internet, a problem solving approach. South Western: Harcourt College Publishers.

Martins, B. (1995).Marketing Research: A South African Perspective, $1^{\text {st }}$ Edition, Pretoria: Unisa Press.

Mouton, E. B. J., (2006). The Practice of Social Research, Oxford Press, London.

Nath, R.,Shrick, P. \& Parzinger, M. (2001).Bankers Perspectives on Internet Banking, e-Service Journal, Indiana University Press.

Network User Address (NUA), (2010). [Online] Available: www.nua.ie.com. (August 24, 2010).

Oppenheim, R.P. (1992).Qualitative Research Theory: Method and Practice, $2^{\text {nd }}$ Edition, London: Sage Publications.

Papazoglou, M. P. \& Ribbers, P. M. A. (2006).e-Business: Organizational and technical foundations, USA: John Wiley and Sons Ltd.

Rod, M, Ashill, N. J., Shao, J. \& Carruthers, J.(2009). An examination of the relationship between service quality dimensions, overall ebanking services and customer satisfaction. Marketing Intelligence \& Planning, 27(1), pp103-126.

Singh, J. \& Wilkes, R. E. (1996).When Consumers Complain: A Path Analysis of the Key Antecedents of Consumer Complaint Response Estimates. Journal of the Academy of Marketing Science. 24(4), pp350-365.

Tustin, D. H, Ligthelm, A. A., Martins, J. H. \& van Wyk, H. de J. (2003). Marketing Research in Practice. Pretoria: Unisa Press. Guide to online banking. [Online] Available: www.helium.com (August 23, 2009).

Internet Banking - An Overview. [Online] Available: www.uob.com. (August 23, 2009).

Talent Management Solutions. [Online] Available: www.custominsight.com/articles/random-sample-calculator.asp. (October 26, 2010). 